\title{
The Patient Satisfaction Survey: What does it mean to your bottom line?
}

\author{
Kristin A. Petrullo, Stacey Lamar, Oby Nwankwo-Otti, Kinta Alexander-Mills, Deborah Viola \\ New York Medical College, School of Health Sciences and Practice, Department of Health Policy and Management, Valhalla, \\ New York, United States \\ Correspondence: Kristin A. Petrullo. Address: New York Medical College, School of Health Sciences and Practice, \\ Department of Health Policy and Management, Valhalla, New York 10595, United States. E-mail: kpetrullo_rd@yahoo.com \\ Received: June 1, 2012 \\ Accepted: November 4, 2012 \\ Online Published: December 10, 2012 \\ DOI : $10.5430 /$ jha.v2n2p1 \\ URL: http://dx.doi.org/10.5430/jha.v2n2p1
}

\begin{abstract}
The primary objective of the Affordable Care Act (ACA) is to improve the health care delivery system for all Americans. In April 2011, a reward system initiative for hospitals was announced that focused enhanced reimbursement incentives to hospitals that improved overall care and maintained patient satisfaction. This initiative began in fiscal year 2013 for Medicare insured patients and is anticipated that private insurers will soon follow this standard.

Patient satisfaction has become one of the determinants of health care. Its measures include access, outcome, effectiveness of service provided, and other variables intended to improve population health. Important economic decisions are being influenced with this data. This study explores the impact of the patient satisfaction survey instrument with reimbursement and how this process has influenced care decisions of one large health system in the northeast. It identifies strengths and weaknesses within this health system that have affected the bottom line.
\end{abstract}

\section{Key words}

Patient satisfaction, Quality of care, Financing, Medicare reimbursement, Hospital Consumer Assessment of Healthcare Providers and Systems, Affordable Care Act, Partnership for patients

\section{I ntroduction}

In an effort to improve the healthcare delivery system in the United States, policymakers have introduced changes in the way hospitals are being reimbursed for Medicare services. The goal is to make hospitals more accountable for the clinical services that they provide by withholding a small percentage of revenue they received under the old reimbursement model thereby incenting hospitals to earn that percentage back based on improved patient outcomes and sustained patient satisfaction. Fiscal year 2013 marks the beginning of this reimbursement model change. The Partnership for Patients initiative developed through the Affordable Care Act (ACA) focuses on quality of care through the eyes of the patient and forces hospitals to improve service or risk losing money ${ }^{[1]}$. This reward system is based on measurement outcomes determined through patients' responses to the patient satisfaction survey. The implementation of this new reimbursement model transfers significantly more power to the patient within the healthcare delivery system. The patients' reported information, via the satisfaction survey, will provide vital information that will either translate into revenue loss or gain for 
hospitals. The intent is to create a healthcare delivery system that is more effective, accountable and transparent, yielding better patient outcomes.

Patient satisfaction and the value of the patient experience have been recognized for decades. The United Kingdom first acknowledged the importance of public opinion in health care in 1984 with the publication of the Griffith's Report ${ }^{[2]}$. This report recommended that health services should integrate the public's opinion and perception into care. Since this report, many variations of the patient survey have been developed and tested. In the United States the Centers for Medicare and Medicaid Services (CMS) began development of a survey instrument and data collection methodology to measure patient satisfaction in the hospital experience starting in 2002. The survey instrument Hospital Consumer Assessment of Healthcare Providers and Systems (HCAHPS) is the first national standard for collecting patient's perspectives of care and enabling valid comparisons across hospitals ${ }^{[3]}$. It was developed to monitor patient satisfaction based on information collected by a questionnaire survey of discharged hospital patients regarding their hospital stay. Patient responses that do not support the integrity of these topics threaten reimbursement to hospitals nationwide.

This change in Medicare reimbursement policy alters the management and planning of hospitals in an effort to secure their maximum reimbursement potential. Tremendous value has been placed in the measure of patient satisfaction through the HCAHPS survey. It is imperative that hospitals react and respond appropriately to protect their bottom line, as history has shown that private insurers tend to follow the Medicare trend within a few years of successful policy changes.

This case study focuses on financial and statistical data from a hospital system in the northeast and projects the change in reimbursement after the fiscal year 2013 model change in Medicare reimbursement. It identifies the strategies utilized by this hospital to improve patient satisfaction outcomes to optimize Medicare reimbursement.

\section{Background}

Government policy is becoming more focused on reducing health care expenditures and improving access and quality of care in the United States. With approximately 17.6\% of the Gross Domestic Product (GDP) spent on health care in 2009 and projected increases in the next decade, change is essential. The ACA, which was passed into law in 2010, offers several solutions to create sustainable change in health care delivery in the United States. "Value-Based Purchasing" is a reward system for hospitals that meet the quality standards developed by CMS. These standards incorporate quality of care with reported levels of patient satisfaction that are determined by survey instruments. Patient satisfaction is recognized as a key performance indicator ${ }^{[4]}$. This is the first time in the United States that patient satisfaction measurement will directly affect reimbursement to hospitals.

In the United Kingdom, the importance of perceived patient satisfaction dates back to the early 1980's with the Griffith's Report $^{[2,5,6]}$. This report suggested that patient opinions should be incorporated in health services and recommended this change to the British National Health Service. Patients' choices and views were explored through patient satisfaction surveys. The British government implemented findings from the Griffith's Report in an effort to contain the rising cost of health care. They established that the patient was the best judge of quality of care ${ }^{[7]}$. In an effort to improve patient safety and quality, patient satisfaction measurement tools began to be developed.

Patient satisfaction is a personal evaluation of health care services and providers ${ }^{[8]}$. Tools developed to measure patient satisfaction have varied over time, but they generally take one of two forms: episode-specific or general ${ }^{[9]}$. Episode-specific questions solicit information about a patient's experience during a specific event such as hospital stay, while general questions do not. A review of the literature by Thiedke ${ }^{[10]}$ cautions that patient satisfaction studies are conducted primarily on one-time events and that "quality of care is not what is being measured in patient surveys." She states that this question is intentionally avoided by survey designers since patients are not in a position to appropriately answer this question. Patient satisfaction surveys ask general questions regarding patient experience that include their 
impression of communication and responsiveness to their needs. Yet studies support that satisfied patients are the ones that have more health improvement ${ }^{[10]}$.

In the United States, Medicare is the largest single payer for hospital services as compared to commercial managed care organizations and self-pay patients ${ }^{[11]}$. In 2002, CMS and the Agency for Healthcare Research and Quality (AHRQ) initiated development of the HCAHPS survey. This survey development was completed in October 2006 and was initially implemented by hospitals as a voluntary measurement tool. It is distributed to patients after discharge from a hospital to determine patient experience based on specific criteria within the following nine domains:

- $\quad$ Communication with nurses

- Communication with doctors

- Responsiveness of hospital staff

- Hospital environment, cleanliness, and noise

- Pain

- Communication regarding medications

- Discharge

- Global overall rating

- Willingness to recommend

The HCAHPS survey consists of up to 27 questions asking patients to rate their perception of the care received by doctors and nurses, the hospital environment, and other experiences. Most answers are based on a Likert-like scale to maintain consistency in reporting and analysis. Although previously a voluntary hospital measurement tool, in July 2007, CMS encouraged all hospitals to collect and report HCAHPS data as a means to receive full reimbursement for Medicare covered services, thus creating the shift in financial importance of the HCAHPS survey. In March 2008 a Hospital Compare Website http://www.hospitalcompare.hhs.gov was introduced for public viewing. At present, these results are published quarterly ${ }^{[1,12,13]}$.

At the beginning of fiscal year 2013, Medicare began withholding 1\% of hospital reimbursement across the country, leaving about $\$ 850$ million to fund value-based incentive payments, shifting the pay-for-reporting model to pay-for-performance. The amount withheld will increase by $0.25 \%$ every year and will be capped at $2 \%$ in 2017 and beyond. Incentive payments will be based on how each hospital performs in twenty-five core measures including seventeen clinical process-of-care measures based on "best practice" standards determined by CMS, and eight measures based on HCAHPS ${ }^{[14]}$. Each measure has been assigned a baseline attainment threshold, a minimal level of performance required to earn points for that measure, and a benchmark value. Each year the attainment threshold and benchmark value will change based on the previous year's scores of all hospitals in the country. Hospitals can also earn points for improvement from year to year and consistency points based on the performance of other hospitals. In fiscal year 2013, HCAHPS scores will affect more than 3,000 hospitals and account for 30\% toward the final score and any unearned incentive dollars will be pooled and used for additional quality incentives ${ }^{[15]}$.

The Medicare reimbursement transition from paying for volume of care provided to paying for services based on efficiency and quality of care is pivotal in our country's need to reign in health care costs, improve access, and shift our current delivery system to a more efficient and quality driven model. This incentive provides hospitals an opportunity to meet these goals as measured by patient satisfaction outcomes and is also one of the ways towards health care change that is currently in progress. The restructuring of the Medicare payment system is intended to create more collaborative relationships with CMS, the government, hospitals, physicians, and other health care providers and thereby create more 
joint financial accountability. Yet, this reimbursement shift has created new challenges for hospitals to assess and respond more effectively to patient satisfaction as a means to preserve all potential Medicare reimbursement they are entitled to. Hospitals are responding to this financial change by implementing policy and protocol guidelines that will meet the expectations of CMS and secure the best reimbursement possible.

Table 1. Literature review

\begin{tabular}{|c|c|c|c|c|c|c|c|c|c|c|}
\hline $\begin{array}{l}\text { Lead } \\
\text { Author }\end{array}$ & Article Title & \# & $\begin{array}{l}\text { Journal } \\
\text { Name }\end{array}$ & $\begin{array}{l}\text { Pub } \\
\text { Year }\end{array}$ & $\begin{array}{l}\text { Study } \\
\text { Design }\end{array}$ & Setting & $\begin{array}{l}\text { Sample N/ Dta } \\
\text { Source } \\
\end{array}$ & Outcome Measures & $\begin{array}{l}\text { Study } \\
\text { Population } \\
\end{array}$ & Summary/Notes \\
\hline Elliott, M & $\begin{array}{l}\text { Hospital Survey } \\
\text { Shows Improvements } \\
\text { in Patient Experience }\end{array}$ & 1 & $\begin{array}{l}\text { Health } \\
\text { Affairs }\end{array}$ & 2010 & $\begin{array}{l}\text { Longitudin } \\
\text { al }\end{array}$ & n/a & $\begin{array}{l}\mathrm{N}=3863 / \\
\text { HCAHPS }\end{array}$ & $\begin{array}{l}\text { Comparison of } \\
\text { reported hospital } \\
\text { scores on HCAHPS } \\
\text { survey in } 2008 \text { and } \\
2009\end{array}$ & $\begin{array}{l}>18 \text { years old } \\
\text { after inpatient } \\
\text { stay of }>l=1 \\
\text { night }\end{array}$ & $\begin{array}{l}\text { *Non-response bias is likely as response } \\
\text { rate is } 34 \% .{ }^{*} \text { Hospitals use HCAHPS } \\
\text { scores to improve quality of care. }{ }^{*} \text { Most } \\
\text { hospitals see in increase in patient } \\
\text { satisfaction scores when using } \\
\text { HACHPS feedback to improve the } \\
\text { patient experience. }\end{array}$ \\
\hline $\begin{array}{l}\text { Fitzpatrick, } \\
\mathrm{R}\end{array}$ & $\begin{array}{l}\text { Surveys of pt. } \\
\text { Satisfaction: II - } \\
\text { Designing a } \\
\text { Questionnaire and } \\
\text { Conducting a Survey }\end{array}$ & 2 & BMJ & 1991 & $\begin{array}{l}\text { Literature } \\
\text { review }\end{array}$ & $\mathrm{n} / \mathrm{a}$ & $\mathrm{n} / \mathrm{a}$ & $\mathrm{n} / \mathrm{a}$ & n/a & $\begin{array}{l}\text { *Descriptive review of various survey } \\
\text { techniques. }\end{array}$ \\
\hline Khayat, K & $\begin{array}{l}\text { Patient Satisfaction } \\
\text { Surveys as a Market } \\
\text { Research Tool for } \\
\text { General Practices }\end{array}$ & 3 & $\begin{array}{l}\text { British } \\
\text { Journal of } \\
\text { General } \\
\text { Practice }\end{array}$ & 1994 & $\begin{array}{l}\text { Multivariat } \\
\text { e analysis }\end{array}$ & $\begin{array}{l}\text { Voting } \\
\text { districts in } \\
\text { Kent }\end{array}$ & $\begin{array}{l}\mathrm{N}=2173(>3100 \\
\text { surveys sent)/ } \\
\text { Postal } \\
\text { questionnaire } \\
\text { survey }\end{array}$ & $\begin{array}{l}\text { Satisfaction with PCP, } \\
\text { access, wait times }\end{array}$ & $\begin{array}{l}\text { Adult } \\
\text { population }\end{array}$ & $\begin{array}{l}\text { *Discusses a study designed to assess } \\
\text { patient satisfaction as it becomes more } \\
\text { relied upon by the British Government } \\
\text { as showing high level primary care. }\end{array}$ \\
\hline Lees, C & $\begin{array}{l}\text { Measuring the Patient } \\
\text { Experience }\end{array}$ & 4 & $\begin{array}{l}\text { Nurse } \\
\text { Researcher }\end{array}$ & 2011 & $\begin{array}{l}\text { Literature } \\
\text { Review }\end{array}$ & $\mathrm{n} / \mathrm{a}$ & $N=3863$ & $\mathrm{n} / \mathrm{a}$ & $\mathrm{n} / \mathrm{a}$ & $\begin{array}{l}\text { *Discusses approaches to gather patient } \\
\text { data that will be most useful in } \\
\text { interpretation. Brief review of how pt. } \\
\text { sat became important. }\end{array}$ \\
\hline Nguyen, T & $\begin{array}{l}\text { Determinants of } \\
\text { Patient Satisfaction in } \\
\text { Ambulatory } \\
\text { Oncology: a } \\
\text { Cross-sectional study } \\
\text { Based on the OUT } \\
\text { PAT-SAT } 35 \\
\text { Questionnaire }\end{array}$ & 5 & $\begin{array}{l}\text { BMC } \\
\text { Cancer }\end{array}$ & 2011 & $\begin{array}{l}\text { Multicenter } \\
\text { prospective } \\
\text { cohort } \\
\text { survey } \\
\text { study }\end{array}$ & $\begin{array}{l}\text { Outpatient } \\
\text { ambulatory } \\
\text { chemo/ } \\
\text { radiation tx. } \\
\text { centers }\end{array}$ & $\mathrm{n}=692$ & $\begin{array}{l}\text { Perception of care, } \\
\text { sociodemographic } \\
\text { variables, and } \\
\text { self-reported quality } \\
\text { of like }\end{array}$ & $\begin{array}{l}\text { Outpatient } \\
\text { cancer pts tx'd } \\
\text { with chemo or } \\
\text { radiation }\end{array}$ & $\begin{array}{l}\text { *Statistical significance in perception of } \\
\text { care and certain sociodemographic } \\
\text { factors. }\end{array}$ \\
\hline Ryan, A & $\begin{array}{l}\text { The Effect of the } \\
\text { MassHealth Hospital } \\
\text { Pay-for-Performance } \\
\text { Program on Quality }\end{array}$ & 6 & $\begin{array}{l}\text { Health } \\
\text { Services } \\
\text { Research }\end{array}$ & 2011 & $\begin{array}{l}\text { Longitudin } \\
\text { al }\end{array}$ & n/a & $\begin{array}{l}\mathrm{N}=62 \mathrm{MA} \\
\text { hospitals and } \mathrm{N}= \\
3,676 \text { from other } \\
\text { states } / \text { Hospital } \\
\text { Compare, PHQID }\end{array}$ & $\begin{array}{l}\text { Used Hospital } \\
\text { Compare to determine } \\
\text { if P4p improved } \\
\text { patient outcomes for } \\
\text { pneumonia and } \\
\text { surgical infection } \\
\text { prevention }\end{array}$ & $\begin{array}{l}\text { MassHealth } \\
\text { hospital P4P } \\
\text { program }\end{array}$ & $\begin{array}{l}\text { *MassHealth P4P program did not } \\
\text { improve quality of care for pneumonia } \\
\text { or surgical infection prevention despite } \\
\text { generous financial incentives. }\end{array}$ \\
\hline Sitzia, J & $\begin{array}{l}\text { How Valid and } \\
\text { Reliable are Patient } \\
\text { Satisfaction Data? An } \\
\text { Analysis of } 195 \\
\text { Studies }\end{array}$ & 7 & $\begin{array}{l}\text { Internation } \\
\text { al Journal } \\
\text { for Quality } \\
\text { in Health } \\
\text { Care }\end{array}$ & 1999 & $\begin{array}{l}\text { Literature } \\
\text { Review }\end{array}$ & $\begin{array}{l}\text { Internation } \\
\text { al research } \\
\text { published } \\
\text { in } 1994 \text { in } \\
139 \\
\text { journals }\end{array}$ & $\begin{array}{l}\mathrm{N}=195 \text { papers } \\
\text { published in } 1994 \\
\text { in } 139 \text { journals/ } \\
\text { British Nursing } \\
\text { Index, CINAHL, } \\
\text { EMBASE, } \\
\text { MedLine, Popline, } \\
\text { and PsycLIT }\end{array}$ & $\begin{array}{l}\text { Number and types of } \\
\text { strategies used for } \\
\text { content, criterion, and } \\
\text { construct validity, and } \\
\text { for stability and } \\
\text { internal consistency. } \\
\text { Associations between } \\
\text { validity/reliability and } \\
\text { other study } \\
\text { characteristics }\end{array}$ & $\begin{array}{l}\text { Published } \\
\text { patient } \\
\text { satisfaction } \\
\text { research }\end{array}$ & $\begin{array}{l}\text { *Purpose: assess the properties of } \\
\text { validity and reliability of instruments } \\
\text { used to assess satisfaction. *The study } \\
\text { instruments in this sample demonstrated } \\
\text { little evidence of reliability or validity. } \\
\text { *The study authors exhibited a poor } \\
\text { understanding of the importance of these } \\
\text { properties in the assessment of } \\
\text { satisfaction. }\end{array}$ \\
\hline Thiedke, C & $\begin{array}{l}\text { What do we Really } \\
\text { Know About Patient } \\
\text { Satisfaction }\end{array}$ & 8 & $\begin{array}{l}\text { Family } \\
\text { Practice } \\
\text { Manageme } \\
\text { nt }\end{array}$ & 2007 & $\begin{array}{l}\text { Literature } \\
\text { Review }\end{array}$ & n/a & $\mathrm{n} / \mathrm{a}$ & $\mathrm{n} / \mathrm{a}$ & n/a & $\begin{array}{l}\text { *Discusses patient satisfaction and the } \\
\text { mixed reviews as to its relevance. This } \\
\text { paper makes an important distinction } \\
\text { that pt. measures are generally } \\
\text { "one-time encounters" }\end{array}$ \\
\hline Ware, J & $\begin{array}{l}\text { Defining and } \\
\text { measuring patient } \\
\text { satisfaction with } \\
\text { medical care }\end{array}$ & 9 & $\begin{array}{l}\text { Evaluation } \\
\text { and } \\
\text { Program } \\
\text { Planning }\end{array}$ & 1984 & $\begin{array}{l}\text { Methodolo } \\
\text { gical }\end{array}$ & $\begin{array}{l}4 \text { cities } \\
\text { chosen in } \\
\text { U.S. }\end{array}$ & $\begin{array}{l}\text { 323-640 people } \\
\text { per city/ Patient } \\
\text { satisfaction survey }\end{array}$ & $\begin{array}{l}\text { Likert scale patient } \\
\text { sat. questionnaire } 55 \\
\text { items }\end{array}$ & $\begin{array}{l}\text { adult } \\
\text { population }\end{array}$ & $\begin{array}{l}\text { *Describes the development of Pt. Sat. } \\
\text { Quest. Self-administered and measured } \\
55 \text { questions. Empiracally favorable. } \\
\text { Satisfaction surveys are "intentionally } \\
\text { more subjective" }\end{array}$ \\
\hline Werner, R & $\begin{array}{l}\text { Public Reporting on } \\
\text { Hospital Process } \\
\text { Improvements }\end{array}$ & 10 & $\begin{array}{l}\text { Health } \\
\text { Affairs }\end{array}$ & 2010 & $\begin{array}{l}\text { Cross-secti } \\
\text { onal }\end{array}$ & $n / a$ & $\mathrm{~N}=3476 /$ MedPAR & $\begin{array}{l}\text { Calculated condition } \\
\text { specific mortality } \\
\text { rates, LOS, and 30day } \\
\text { readmission rates } \\
\text { every } 6 \text { months } \\
\text { between } 2004 \text { and } \\
2006\end{array}$ & $\begin{array}{l}\text { Acute care, } \\
\text { nonfederal } \\
\text { U.S. Hospitals }\end{array}$ & $\begin{array}{l}\text { *In all hospitals, improvement In } \\
\text { process performance led to decrease In } \\
\text { mortality rates, readmissions, and LOS. } \\
\text { *Hospitals with the lowest baseline } \\
\text { performance according to Hospital } \\
\text { Compare had biggest improvements in } \\
\text { quality once Hospital Compare initiated } \\
\text { whereas hospitals with a high baseline } \\
\text { performance continued to provide high } \\
\text { level care. *Despite the improvements } \\
\text { in low scoring hospitals, they would still } \\
\text { not meet the minimum for a } \\
\text { pay-for-performance reward. }\end{array}$ \\
\hline
\end{tabular}

Despite the monetary emphasis being placed on HCAHPS scores, there are limitations to the survey and confounding variables that may not make it a reflection of high quality medical treatment. Hospitals choose to administer the survey via telephone, active interactive voice response, or mail in Elliott et al. ${ }^{[16]}$ found that telephone surveys receive more positive feedback than mail in surveys, providing hospitals with an advantage of at least 30 percentile points in ranking. This may 
be caused by the interviewer influencing the composition of respondents, by having an effect on the way they answer questions leading to response bias. Respondents may also have a predisposition to choose the last option in an auditory list when compared to a visual list, known as the recency effect. Variables such as age, race, and education level are not controlled by a hospital but are related to a patient's experiences and responses. For example, a young, well-educated patient is more likely to be dissatisfied with hospital care than older, less educated patient. The CMS attempt to improve the validity of the HCAHPS survey by controlling for type of survey administered and patient mix ${ }^{[16]}$.

The ACA was developed in part to contain healthcare costs while focusing on quality of care. In a recent survey done by Emergency Physician Monthly, of the 717 respondents, 59\% reported increasing discretionary testing to improve patient satisfaction scores, and $48 \%$ of providers surveyed reported altering medical treatment and providing unnecessary care in order to improve scores. Not only does this cause an increase in healthcare spending on inpatient and prescription drug expenditure, but also an increase in iatrogenic harm, mortality, resistant bacterial infections, kidney damage, and medication overdose ${ }^{[17,18]}$. If this trend continues in order to improve patient satisfaction scores healthcare costs will not be contained, the validity of HCAHPS scores will continue to be questioned, and the new Medicare reimbursement model will be futile.

\section{Methods}

Through a comprehensive literature review, the authors explored the history of the patient satisfaction survey and its evolution in the healthcare system (Table 1). Data collection and evaluation of a large health system in the northeast included assessment of demographic information such as size, patient and payer mix, as well as the implemented changes within this system directly related to the financial impact of "value based purchasing". Current patient satisfaction scores were reviewed comparative to the national average within similar settings and the potential financial loss has been approximated and reported. This study reviews the significant financial impact this health system is currently challenged by and discusses the reported changes that are being considered to make immediate improvement. Key mesh terms used for the search included: Patient satisfaction, quality of care, financing, Medicare reimbursement, Hospital Consumer Assessment of Healthcare Providers and Systems, Affordable Care Act, Partnership for Patients.

\section{Results}

The metropolitan New York hospital system reviewed within this study is implementing several changes to address patient needs, improve satisfaction scores, and satisfy the current reimbursement modifications within the Medicare system which affect hospitals nationwide. Anonymity of the hospital reviewed will remain throughout discussion within this study.

This metropolitan hospital system maintains approximately 500 beds throughout its region and provides community care in a variety of settings and specialties including medical and surgical care, geriatrics, obstetrics and gynecology, orthopedics, oncology, and extensive emergency and trauma services. It maintains accreditation by the Joint Commission on Accreditation of Healthcare Organizations (JCAHO) and has unconditional tax exemption, lending to its not-for-profit status ${ }^{[19,20]}$. The reported income was greater than $\$ 490$ million, which is approximately $\$ 30$ million more than similar organizations. It reportedly employs more than 1,500 people with approximately $35 \%$ of employees earning more than $\$ 50,000$ annually.

Prior to implementation of change in reimbursement guidelines by CMS, patient satisfaction was a priority within this hospital system. The Mission Statement maintains this hospital's dedication to providing quality healthcare to people within its community. It further recognizes the importance of integrity, compassion, confidentiality, and caring as critical components of quality hospital based care. This hospital system is located in a very diverse area of metropolitan New York that serves a high proportion of minority patients who are without health insurance. It is estimated that the payer mix includes approximately 35\% Medicaid, 50\% Medicare, and nearly 15\% private insurance (Figure 1). Additionally, this 
health system serves approximately $15 \%$ uninsured patients identified as "bad debt" within the hospital budget. Providing care for this large number of uninsured patients is a challenge to this hospital's economic viability. The additional reduction of revenue by the current CMS restructuring of repayment for service places an additional burden on the facility to secure reimbursement that is vital to its existence. In response to the outlined Medicare reimbursement changes, this hospital has become more aggressive in monitoring the patient's experience, a process that has occurred simultaneously with the introduction of an electronic medical records system in the fall of 2011 to improve patient services, reduce medical errors, and maintain quality compliance in the medical record.

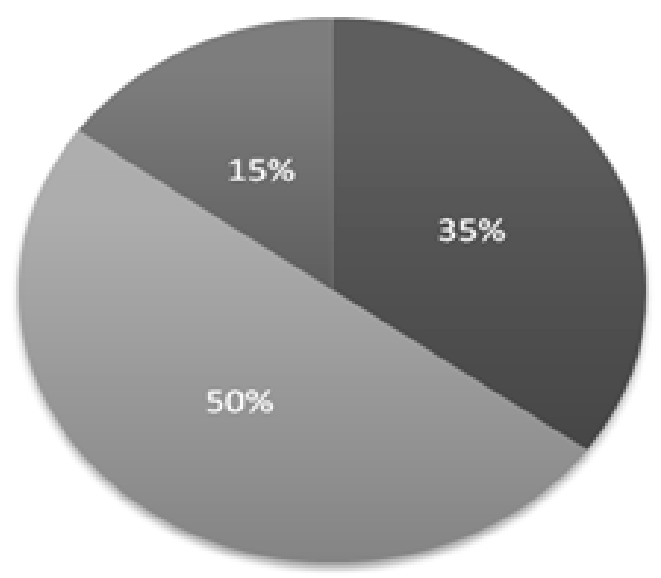

Figure 1. Metropolitan New York Hospital System Estimated Payer Mix, 2012 medicaid = Medicare = Private/Other

In response to the need to improve patient satisfaction to secure Medicare reimbursement, this hospital contracted with a local consulting team. This team was hired to assess, evaluate, and implement change within the hospital system with the goal of improving patient satisfaction scores. The consulting team provides comprehensive assessment of targeted departments within the hospital that are part of the reimbursement process by CMS. Each department is assessed by the consulting team through observations and personal interviews of employees and patients to identify strengths and weaknesses as a means to improve patient satisfaction ratings. The consulting team targets physicians and nurses as their interactions with patients contribute to the largest percentage of the HCAHPS survey. It is the communication by these medical professionals that serves as the most significant measure of the patient experience and is responsible for several of the nine domains including communication and patient's perceived understanding of pain management, treatment plan, discharge plan, and the patient's perception of physician and nurses responsiveness to personal needs.

This consulting team has been in place in this hospital system for approximately seven months. To date, it has spent the majority of time interviewing the nurses within specific hospital units to determine the nursing staffs' individual perceptions of the strengths and weaknesses of the units. The consultants also conduct personal in-patient interviews and report the findings to hospital administration as well as the nursing team. Currently, the hospital has maintained regional average patient satisfaction scores within most specialties; however the most recent satisfaction scores have declined in some areas thus creating concern about fiscal reimbursement. With 1\% of Medicare reimbursement withheld by CMS, the Metropolitan New York Hospital System has potential to lose \$2 million this fiscal year and continue to rise to the proposed 2\% cap is reached, resulting in a $\$ 4.9$ million deficit per year after five years (Figure 2). Thus, the consultants are in collaboration with nursing staff to develop creative solutions to improve patient satisfaction in these specialized areas.

The most distressing weakness in satisfaction scores is that patients report lack of communication by nursing staff and lack of teaching regarding pain management. It has been stated that some nurses do not appear to communicate with consistent kindness or appearance of having a "caring outlook" about the patients. This significant problem is currently under review 
and an option to create universal standards of communication for nurses in the specialized units has been suggested as a means to eliminate this problem. It is believed that universal guidelines that require each nurse to introduce themselves and greet and educate patients in a standardized format will eliminate discrepancy in this area of communication.

Figure 2. Metropolitan New York Hospital System Potential Deficit due to Value Based Purchasing (per year)

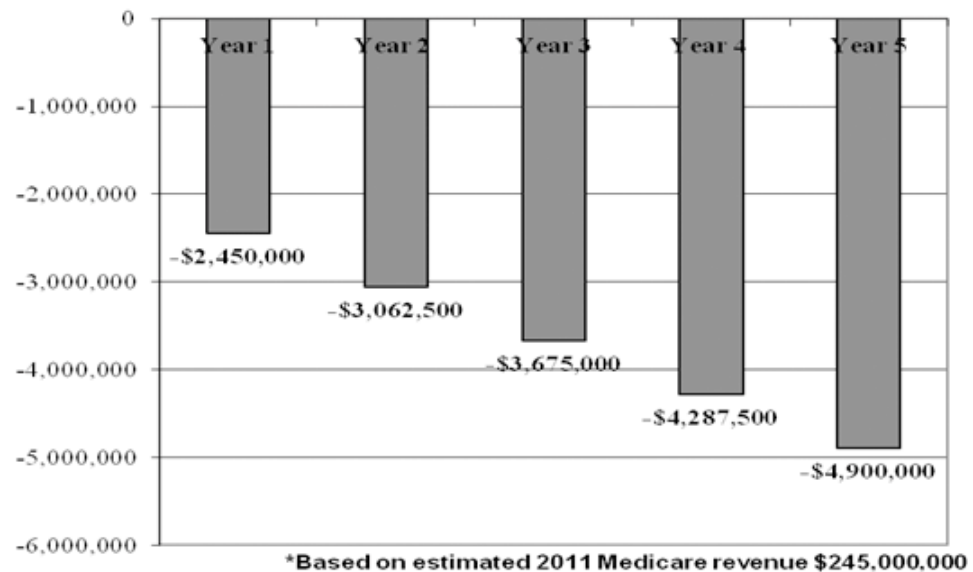

In addition to consulting services, this hospital has also contracted with a patient satisfaction survey company that monitors patient satisfaction for a reported fifty percent of United States hospitals. This survey company markets their ability to improve healthcare facility outcomes in the face of the new challenges of value-based purchasing. Their vision includes improving quality of healthcare through assessment of the people who deliver it. This company has been hired to conduct random outpatient surveys via telephone for this hospital and assess the response trends and make recommendations for improvement. They also conduct personal interviews of staff within the hospital units to determine the reported strengths and weaknesses by the employees.

\section{Conclusion}

This hospital has responded swiftly in the face of economic change. They are feeling pressure by the withholding of a proportion of Medicare reimbursement and are making financial investments in consulting companies that offer promise of better Medicare payment. Recent declines in patient satisfaction scores with regard to nursing care prompted leadership to conduct more frequent educational sessions with staff to reinforce hospital expectations regarding care. Current discussions that include implementation of universal nursing protocols are underway, yet no decisions are complete as of yet. The belief that patient satisfaction begins with the first introduction to the hospital setting is motivating conversations regarding a universal protocol system. The nursing staff may be more successful with patient satisfaction if they work within a delineated model of meeting patients and explaining care that is consistent hospital wide. Immediate remedy includes more frequent education sessions for nursing to reinforce appropriate methods of communication with patients that include being pleasant, smiling, eye contact, and ensuring that each patient feels the nurse is empathetic.

The change in Medicare reimbursement has facilitated an increase in the awareness of nursing personnel with regard to the importance of how their performance affects the hospital's bottom line. Nurses report that prior to interviews with the consulting teams they had no knowledge of the significance of their role in the current financial model. Therefore, continued education for all staff is perceived as beneficial to outcomes. Although the nurses acknowledge their contribution to patient satisfaction they overwhelmingly maintain that the questions within the HCAHPS survey do not adequately establish a correlation between the quality of care they provide and patient satisfaction. Physicians and nurses collectively state that the current survey places too much emphasis on levels of patient satisfaction that do not determine 
sound evidence based clinical care. Therefore, the hospital they work for may suffer financially from unsatisfactory outcomes despite the best clinical care given. Additionally, medical staff cautions that relative to similar hospitals within their community, the hospital provides care for many more ethnic minorities that are significantly more disparate than the populations of their competitors. Thus, outcome measures should be more reflective of the patient population demographics rather than a nationwide carbon copy.

Concerns about the potential for reimbursement model changes occurring within the other payer systems are becoming a reality. Physicians report that they are being advised that a few local insurance companies are now discussing withholding hospital reimbursement based on hospital patient satisfaction as well. It appears that the perceived threat of private insurers following the Medicare model in a few years has only taken a few months.

\section{References}

[1] United States Department of Health and Human Services. Partnership for patients' initiative to improve hospital care. [Internet]. Available from: http://www.hhs.gov (May 2012).

[2] Khayat, K. \& Salter, B. Patient satisfaction surveys as a market research tool for general practices. British Journal of General Practice. 1994; 44: 215-219. PMid:8204335

[3] Centers for Medicare and Medicaid Services. HCAHPS: Patient's perspectives of care survey [Internet]. Available from: http://www.cms.gov (May 2012).

[4] Nguyen, T.V.F., Bosset, J.F., Monnier, A., Fournier, J., Perrin, V., Baumann, C., Bredart, A., \& Mercier, M. Determinants of patient satisfaction in ambulatory oncology: a cross sectional study based on the OUT-PATSAT35 questionnaire. BioMed Central Cancer. 2011; 11: 526. http://dx.doi.org/10.1186/1471-2407-11-526

[5] McIver, S. Obtaining the views of outpatients. Kings Fund. London.

[6] Sitzia, J. \& Wood, N. Patient satisfaction: A review of issues and concepts. Social Science Medicine. 1997; 45(12): $1829-1843$. http://dx.doi.org/10.1016/S0277-9536(97)00128-7

[7] Lees, C. Measuring the patient experience. Nurse Researcher. 2011; 19(1): 25-28. PMid:22128584

[8] Ware, J.E., Snyder, M.K., Wright, W.R., \& Davies, A.R. Defining and measuring patient satisfaction with medical care. Evaluation and Program Planning. 1983; 6: 247-263. http://dx.doi.org/10.1016/0149-7189(83)90005-8

[9] Fitzpatrick, R. Surveys of patient satisfaction: II - designing a questionnaire and conducting a survey. British Medical Journal. 1991; 302: 1129-1131. http://dx.doi.org/10.1136/bmj.302.6785.1129

[10] Thiedke, C. A review of the literature reveals practical ways to improve patient satisfaction and compelling reasons to do so. Family Practice Management. 2007; 14(1): 33-36. PMid:17294978

[11] United States Department of Health and Human Services (2011). Administration implements new health reform provision to improve care quality, lower costs. [Internet]. Available from: http://www.healthcare.gov (May 2012).

[12] Press Ganey. HCAHPS implementation timeline - upcoming dates in history [Internet]. Available from: http://www.pressganey.com (May 2012).

[13] United States Department of Health and Human Services (2012). Hospital Compare [Internet]. Available from: http://www.hospitalcompare.hhs.gov (May 2012).

[14] Centers for Medicare and Medicaid Services. (2012b). NHE factsheet [Internet]. Available from: http://www.cms.gov (May 2012).

[15] Nelson, B. Value based purchasing raises the stakes: as Medicare pins big money on quality hospitals demand more from hospitalists. The Hospitalist [Internet] Available from: http://www.the-hospitalist.org/ (May 2012).

[16] Elliott, M.N., Zaslavsky, A.M., Goldstein, E., Lehrman, W., Hambarsoomians, K., Beckett, M.K., and Giordano, L. Effects of survey mode, patient mix, and nonresponse on CAHPS hospital survey scores. HSR: Health Services Research, 2009. http://dx.doi.org/10.1111/j.1475-6773.2008.00914.x

[17] Fenton, J.J., Bertakis, K.D., \& Franks, P. The cost of satisfaction: a national study of patient satisfaction, health care utilization, expenditures, and mortality. Archives of Internal Medicine. 2012. http://dx.doi.org/10.1001/archinternmed.2011.1162

[18] Zusman, E.E. HCAHPS replaces Press Ganey survey as quality measure for patient hospital experience. Neurosurgery Science Times. 2012; 71(2): N21-N24.

[19] American Hospital Directory. Hospital Profile. [Internet] Available from: http://www.ahd.com/free_profile (May 2012).

[20] Tax Exempt Organizations. Hospital data [Internet]. Available from: http://www.faqs.org (May 2012). 